\title{
Quality of live packaged mussels during storage as a function of size and oxygen concentration
}

Marta Bernárdez*, Laura Pastoriza

Instituto de Investigaciones Marinas (IIM-AECSIC). Eduardo Cabello, 6. 36208. Vigo. Spain

Author to whom correspondence should be addressed

Name: Marta Bernárdez Costas

Address: Instituto de Investigaciones Marinas (IIM-AECSIC). Eduardo Cabello, 6 - 36208 Vigo (Spain)

Telephone number: 34986214465

Fax number: 34986292762

E-mail: mbernar@iim.csic.es 


\section{ABSTRACT}

The commercialization of live mussels is limited by their capacity to resist the adverse conditions associated with their removal from the natural environment. Packaging under modified atmospheres has been proposed as an alternative method for the stabilization of mussels and shelf life extension. This study investigates how different concentrations of oxygen (20,75 and $85 \%)$ influence the percentage mortality and quality of packaged Mediterranean mussels (Mytilus galloproviciallis) of different sizes (30 and 44 units $/ \mathrm{kg}$ ). In general, mussels packaged with oxygen-rich atmospheres had a higher organoleptic rating and lower percentage mortality. The decrease in $\mathrm{pH}$ of both the tissues and intervalval fluid was less pronounced in the larger mussels compared to the smaller mussels. Mussel size and packaging atmosphere also influenced the metabolic survival strategies. The smaller mussels produced more ammonium and volatile fatty acids, which decreased as initial oxygen increased. After 10 days of storage no consumption of glycogen was detected in any of the samples analyzed. The marketable period for the mussels, defined as a $20 \%$ mortality threshold, was reached earlier in the packages displaying a greater accumulation of acidic and basic metabolites.

KEYWORDS: mussel, refrigerated, modified atmosphere, ammonium, volatile fatty acids 


\section{Introduction}

The mussel is valued worldwide for its sensory and nutritional qualities. According to FAO data, global mussel production surpassed 1,900,000 Tm in 2005, of which the highest percentage originated from aquaculture. In the same year, Spain was the third highest producer (158000 tonnes), mainly due to the cultivation of Mytilus galloprovincialis on the Galician coast. The environmental conditions of food availability and temperature in this zone afford high mussel growth rates and a commercial size of $60-80 \mathrm{~mm}$ in $1-1.5$ years (Pérez Camacho, González \& Fuentes, 1991). Total trade in live, fresh and frozen mussel trade is expanding, and reached almost 237.000 tonnes in volume of exportation in 2004, and of this, $46 \%$ are fresh mussels. The most widely employed form of packaging for trade is the jute bag. However, hermetic packages are a more attractive alternative since inconveniences such as dripping, smells or external contamination are avoided. If the packaging were to have an additional advantage, such as an increase in shelf life, it is foreseeable that its use will increase in the coming years. The latest market reports for bivalves in 2008 already reflect the trade in mussels in modified atmosphere packaging (MAP) with a price of $3.41 \$ / \mathrm{kg}$ (FAO, 2007; FAO, 2008). MAP technology has been successfully used for the conservation of distinct types of fresh or processed foodstuffs and is constantly improving due to advances in packaging materials (Farber \& Dodds, 1995; Svensson, 2004). A further demonstrated advantage of MAP is its effectiveness in keeping molluscs alive, thereby prolonging the marketable period (Pastoriza, Bernárdez, Sampedro, Cabo \& Herrera, 2004). In the scientific literature there are several studies on the conservation of fresh mussel which address, for instance, the evolution of sucked mussels in storage with and without modified atmosphere or kept alive in ice. There are, however, few studies on the quality of live packed molluscs (Erkan, 2005; Goulas, Chouliara, Nessi, Kontominas \& Savvaidis, 2005; Ho, Lee \& Yam, 1997; Khan, Parrish \& Shahidi, 2005).

The behaviour and survival strategies of mussels depend on the local environmental conditions. Accordingly, differences are observed between mussels of wild origin and 
those from submerged culture (Bayne, Thompson \& Widdows, 1976; Babarro, FernándezReirez \& Labarta, 2000). Furthermore, metabolism or the rate of respiration varies according to age, season, time after eating and hypoxia. Storage in hermetic packages provides a special type of environment leading to an increase in survival rate under favourable conditions (Camacho, Labarta \& Navarro, 2000; Sukhotin, Lajus, \& Lesin, 2003; Wang \& Widdows, 1993).

The objective of this study is to compare the efficacy of MAP using a gas mixture with low and high oxygen $\left(\mathrm{O}_{2}\right)$ levels with regards to the storage of different sized live mussels and to determine their quality during the marketable period. Using published methodologies, we further investigate the metabolic response of the animals to determine whether the survival strategies they adopt influence the final quality of the live packed mussels.

\section{Materials and methods}

\subsection{Materials and equipment}

The gas was supplied by Carburos Metálicos (Barcelona, Spain). PS-EVOH-PE 269X179X55 mm barrier containers were supplied by Tecnopack Plastics, S.L (Spain). The packaging machine used in this study was a Reematic 1000 (Reepack, Barcelona, Spain). The proportion of $\mathrm{CO}_{2}$ and $\mathrm{O}_{2}$ in the package headspace was determined using a PAK 12P headspace analyser (Abiss, Barcelona, Spain). Spectrophotometric measurements were carried out on a Cecil 3000 Series Spectrophotometer.

\subsection{Sample collection}

Live Mediterranean mussels (Mytilus galloprovinciallis) from mussel farms in the Ría de Arosa (Galicia, Spain) were collected in autumn 2005, they were transferred to a purification station and were maintained in seawater for $12 \mathrm{~h}$. After mechanical removal of the byssus, the mussels were tightly packed by hand in $1 \mathrm{~kg}$ containers, filled with the corresponding gas and sealed. The mussels were packed under three different atmospheres as a function of the percentage of initial oxygen: atmosphere A (21\%), atmosphere B $(75 \%)$ and atmosphere C (85\%). The batches were classified according to 
size in term of number of mussels by $\mathrm{kg}$, with batch $1=30$ units $/ \mathrm{kg}$ and batch $2=44$ units $/ \mathrm{kg}$. All the packages were stored refrigerated at $2 \pm 1^{\circ} \mathrm{C}$.

\subsection{Proximate composition}

Moisture and ash contents were determined as described in AOAC (1990a, b). The protein content was determined by the Kjeldahl method (2300 Kjeltec Analyzer Unit, Foss Tecator) described by Ribas and Vázquez (1953). The total lipid content was quantified as described in AOAC $(1990 c)$. The carbohydrate content of each sample was determined by difference as $\mathrm{CH}=$ $100-(\%$ moisture $+\%$ ash $+\%$ protein $+\%$ lipid $)$. All results are expressed in dry weight.

\subsection{Quantification of mortality}

Five packages of the three atmospheres of each batch were removed daily for the 14 days of storage. Mortality was evaluated by tapping on gaping bivalve shells, and any shells remaining open were considered dead. The result is expressed in percentage with regards to the number of total units in the 5 packages.

\subsection{Sample preparation for analyses}

Live mussels (22-25) were removed from each batch and opened. The shell liquor and meat were collected separately for analysis. In addition, 25 mussels were dissected and the hepatopancreas was removed for glycogen analysis.

\subsection{Chemical analysis}

The analysis of ammonium content in the samples was based on the oxidation of ammonium to nitrite by the addition of hypochlorite to the alkaline medium following the method of Solorzano and described by Parsons (1984). Ammonium sulphate was used as a standard to obtain a standard curve spanning 2-5 micrograms $/ \mathrm{mL}$ of ammonium nitrogen. The reaction was measured in a spectrophotometer at $640 \mathrm{~nm}$.

Total volatile fatty acids (VFA) were quantified by titration with $0.01 \mathrm{~N} \mathrm{KOH}$ using purple metacresol $(0.04 \mathrm{~g} / 100 \mathrm{~mL}$ ethanol $)$ indicator. The distillation apparatus was standardized following the AOAC protocol (1990d) and the percentage recovery was calculated using acetic acid as a standard. The liquid sample $(25 \mathrm{~mL})$ was acidified to $\mathrm{pH} 3-4$ with sulphuric acid and distilled to a $75 \mathrm{~mL}$ volume in $15 \mathrm{~min}$. The shell liquor samples were used directly. For the mussel tissue sample, $10 \mathrm{~g}$ of meat was weighed and blended with $20 \mathrm{~mL}$ of $100 \%$ methanol, centrifuged at $7200 \mathrm{~g}$ for $10 \mathrm{~min}$ and the supernatant was adjusted to $25 \mathrm{~mL}$ in a volumetric flask. The methanol retains the fatty acids and 
avoids interference of the distillation matrix. The calculation of total VFA, in mg of acetic acid per $\mathrm{mL}$ or gram of sample (equivalent to $\mathrm{g} / \mathrm{L}$ and $\mathrm{g} / \mathrm{kg}$, respectively), is:

$\mathrm{mL} 0.01 \mathrm{~N} \mathrm{NaOH}$ x normality $\times 6.01 \times \%$ recovery

Determination of glycogen was based on a spectrophotometric method using anthrone reagent in sulphuric acid and a glucose standard as described by Fraga (1956). The dried sample was treated with sodium hydroxide and precipitated with absolute ethanol. Freshly prepared anthrone reagent was added to the sample and the reaction was carried out in a water bath at $90{ }^{\circ} \mathrm{C}$ for 16 minutes, cooled in ice water and then measured at $600 \mathrm{~nm}$. The glycogen was calculated considering that $1 \mathrm{mg}$ of glucose is equivalent to $0.9 \mathrm{mg}$ glycogen.

\subsection{Microbiological analysis}

A $25 \mathrm{~g}$ sample ( $20 \mathrm{~g}$ meat and $5 \mathrm{~g}$ shell liquor) was mixed with $225 \mathrm{~mL}$ of $0.1 \%$ peptone water for 1 minute in a Lab-Blender-400 Stomacher. Serial decimal dilutions of the mixture were made in $9 \mathrm{~mL}$ of $0.1 \%$ peptone water. The diluted samples were spread on Plate Count Agar supplemented with $1 \% \mathrm{NaCl}$ and incubated at $20^{\circ} \mathrm{C}$ for $72 \mathrm{~h}$ under aerobic conditions to determine total viable counts (TVC). The results are expressed as log colony forming units (log CFU/g) per sample.

\section{8. $\mathrm{pH}$ measurement of the sample}

Mussel meat, homogenized with water in a 1:2 ratio, and shell liquor were analyzed with a Basic 20 (Crison) $\mathrm{pH}$ meter at $15^{\circ} \mathrm{C}$.

\subsection{Sensorial analyses}

A panel was trained to evaluate the sensory properties of fresh and cooked mussels, which included the odour of the opened package and the odour, taste and texture of the cooked product. Mussels were steam-cooked at $100{ }^{\circ} \mathrm{C}$ for $4-6 \mathrm{~min}$ and they were cooled to approximately $35^{\circ} \mathrm{C}$ before serving the mussel on a half shell to trained panellist. Scoring was conducted on a 10-point scale following Pastoriza et al. (2004).

\subsection{Statistical analysis}

Statistical analysis was used to compare mortality and chemical values of batch 1 and 2 of the fresh mussels packed under different atmospheres. Significant differences between the samples were calculated with Statistica 6.0 package using a Student's test with a significance level of 95\%. 


\section{Results and discussion}

3.1. Changes in mortality, sensorial assessment, gas percentage, $\mathrm{pH}$ and microbial abundance of batch 1 and 2 during storage

The 2 batches defined as a function of mussel shell size were packaged under the three atmospheres (A, B and C). As presented in Table 1, the edible tissue in the large (batch 1) mussels accounted for an extra $57 \%$ of dry weight compared to the small (batch 2) mussels. The results of the proximate analysis also revealed differences between the batches, mainly in fat and ash content.

For each day of the study period, the number of mussels whose valves remained open or semi-open inside the package in response to gentle tapping were considered non-viable or dead (Fig. 1a, 1b). The increase in percentage mortality was much more pronounced for the packages with $21 \%$ initial $\mathrm{O}_{2}$ (atmosphere A) for both batches. However, with respect to the other 2 atmospheres, the largest differences were established from day 8 for batch 1 and from day 2 for batch 2 . From day 8 , the percentage mortality of mussels in atmosphere $A(15 \%$ in batch 1 and $28 \%$ in batch 2$)$ tended to equalize as the number of individuals considered non-viable increased considerably, reaching maximum values close to $40 \%$ at the end of storage. The packages with $75 \%$ initial $\mathrm{O}_{2}$ (atmosphere $\mathrm{B}$ ) had a low percentage mortality until day 10 of storage, although the values for batch 2 were always lower than those for batch 1 . For example, on day 8 the mortality was $7 \%$ for batch 1 and $3 \%$ for batch 2 . Subsequently, however, the percentage mortality of batch 2 increased relative to batch 1 , reaching $27 \%$ and $20 \%$, respectively, on day 13 . The same trends as atmosphere B were observed for the packages with $85 \%$ oxygen (atmosphere C), with mortality reaching $14 \%$ on day 8 for batch 1 and $3 \%$ for batch 2 , whereas on day 14 the values were higher for batch $2(28 \%)$ than batch 1 (20\%). Statistical analysis (Table 2) indicates that there were no significant differences in percentage mortality between batches when packaged with atmosphere B or C. Significant differences between batches could not be established for atmosphere $A$ due to the large variability in percentage mortality of the individuals in batch 2 over the first days of storage. Following this initial 
period, significant differences between batches were noted, until reaching high values from day 13 of storage. For atmospheres $\mathrm{B} / \mathrm{B}$ and $\mathrm{C} / \mathrm{C}$ significant differences were established between 6 and 9 days of storage. A quantification of the mortality rate of molluscs is required in order to establish the best handling methods and the optimum period of commercialization. It has been shown that dry storage of clams reduces postharvest mortality and weight losses and that a temperature of $10^{\circ} \mathrm{C}$ is more favourable for the survival of Tapes decussates, giving low and stable mortality $(<7 \%)$ for approximately 9 days (Ekanem \& Achinewhu, 2006; Sadok, Uglow \& El-Abed, 2003). Pastoriza et al. (2004) also demonstrated that a package filled with an $\mathrm{O}_{2}$-rich atmosphere favoured the survival of mussels, with $10 \%$ mortality on day 6 storage at $2-3^{\circ} \mathrm{C}$.

The proposed criterion for suitability of a packaged product is a minimum $80 \%$ viability (mortality $<20 \%$ ). According to this rating system, the limit was reached for the mussels of batch 1 packaged with atmospheres A, B and C on day 8,13 and 13 , respectively. In batch 2, this limit was reached before day 8 for $A$, before day 13 for $B$ and on day 13 storage for $\mathrm{C}$ (Fig. 1a, 1b). The sensorial quality of the cooked mussels was also assayed using individuals that remained closed (live), regardless of whether the viability threshold was reached. In general, a loss of organoleptic quality of the product during storage was noted. However, even when the packages registered a percentage mortality of $20 \%$ or slightly higher, the sensorial analysis of the cooked product was good or very good (Table 3). The minimal sensorial value obtained was 6 points from a scale of 1 to 10 , with 10 being the highest score. The organoleptic evaluation of batch 2 mussels packaged with atmosphere $B$ was lower than that of the other mussels packaged in oxygen-rich atmospheres, obtaining a score of $6.7 \pm 0.3$ on day 9 ( $8 \%$ mortality). This decreased further in the following days to 4.1 points on day 13 when $20 \%$ mortality was reached. The gradual loss of sensorial quality observed in the batch 1 and 2 mussels for the 3 atmospheres, may be related to the combination of the adaptive metabolic changes and the final metabolic products. A relationship has been observed in clams between the concentration of amine compounds and the number of non-suitable mussels determined 
by sensorial analysis when $50 \%$ mortality was reached (Sadok et al., 2003). Mussels packed with atmosphere A had smaller sensorial quality. Gonçalves, Pedro, Duarte and Nunes (2009), found that enriched oxygen atmosphere has a significant positive effect on the typical sweet taste of clams during storage.

Table 3 also shows the results of the percentage oxygen in the packages and $\mathrm{pH}$ of the intervalval fluid and tissue for the 2 batches of mussel packaged in the 3 different atmospheres (A, B and C) and the initial characteristics of the raw material on day 0 (air). Comparison between batches focussed on day 8 and 13 storage where the maximum limit of viability (mortality < 20\%) was reached, and thus represents the upper limit of conservation for the Mediterranean mussels. A gradual consumption of $\mathrm{O}_{2}$ was observed for all atmospheres throughout the study. The consumption of oxygen in atmosphere $A$ was more pronounced in batch 1 than batch 2, reaching 7.2 and $13 \% \mathrm{O}_{2}$ on day 8 of storage, respectively. In B, the consumption was similar for both batches on day 8 and 13 of storage. For the packages with atmosphere $\mathrm{C}$, the percentage $\mathrm{O}_{2}$ was higher in batch 2 , but reached values which were not significantly different by day 13 of storage. The decrease in $\mathrm{O}_{2}$ inside the packages observed in this work is a result of respiration by the mussels. The same findings have been shown for clams and mussels in closed systems, where a production of $\mathrm{CO}_{2}$ inverse to the consumption of $\mathrm{O}_{2}$ was recorded depending on the storage temperature or the initial concentration of gases in the interior (Ho et al., 1997; Pastoriza et al., 2004).

Different $\mathrm{pH}$ values were registered in the shell liquor and soft tissue throughout storage, whereby the former showed a tendency toward acidification and the variations in the latter were less marked. The $\mathrm{pH}$ in the shell liquor in batch 1 oscillated, reaching a minimum of $\sim 7.0$ for the 3 atmospheres studied (A, B and C). However, in batch 2 the $\mathrm{pH}$ reached lower values for all atmospheres, showing a continual trend in $A$, and similar values in $B$ and $C$ until day 10 at which point there was a clear acidification (complete sequences not shown). Initially ( 0 day), the mean $\mathrm{pH}$ of the shell liquor was 7.3 (Table 3 ) and different between the batches on the same days of storage: 7.08 versus 6.79 with atmosphere $A$ 
(day 8); 6.92 versus 6.72 with atmosphere B (day 13) and 7.01 versus 6.80 with atmosphere $\mathrm{C}$ (day 13). The $\mathrm{pH}$ of the mussel tissue packaged with atmospheres $\mathrm{B}$ and $\mathrm{C}$ was maintained throughout the study at around the initial value of 6.60 in batch 1 and 6.70 in batch 2. However, a greater acidification was observed in the mussel tissue packaged with atmosphere A, and was more pronounced for batch 2 with a value of 6.38 versus 6.46 for batch 1 on day 8 . This trend continued until day 13 when the percentage mortality was higher (38.8\% and $36.9 \%$, respectively) with $\mathrm{pH}$ values of 6.29 in batch 2 and 6.40 in batch 1. Intracellular $\mathrm{pH}$ is considered to be one of the important factors controlling the metabolic rate. To maintain intracellular $\mathrm{pH}$, mussels rely on the buffering capacity of the tissues, the release of protonated end products into the external medium, and the neutralisation of acidic substances by calcium carbonates from the shell (Heisler, 1986; Jokumsen \& Fyhn, 1982). In both batches, the acidification of the intervalval fluid occurred before the tissues in the live individuals analyzed on the days indicated in Table 3, although a decrease in $\mathrm{pH}$ in the tissues of the mussels with atmosphere A was evident on day 8 of storage. Initial $\mathrm{pH}$ values of homogenized mussel samples maintained on ice for 14 days were c.a. 6.4 , thereafter stabilizing at c.a. 6.5 for the entire storage period (Ho et al., 1997). Other workers found low but statistically significant acidification in White Sea mussel tissues when exposed to air for $60 \mathrm{~h}$ at $10{ }^{\circ} \mathrm{C}$, indicating the onset of anaerobic metabolism (Sukhotin \& Portner, 1999).

The total viable count (TVC) of microorganisms was stable within 0.5 log units of the initial value throughout the storage period in all samples. On day 0 , the TVC was $4.18( \pm 0.2)$ and $4.44( \pm 0.3)$ for batch 1 and 2 , respectively. The proposed limit for rejection of live molluscs, log $5 \mathrm{cfu} / \mathrm{g}$, was not reached in any of the experimental batches (Anonymous, 1992). The increase in bacterial numbers may indicate an alteration of tissues in weaker mussels. Some authors argue that the proliferation of certain bacterial groups in molluscs can occur when the defence system is weakened by certain causes such as anoxic stress (de Zwaan, Babarro, Monari \& Cattani, 2002). The mussels used in this study were previously purified and the analyses were restricted to those that remained closed (live) 
and were thus the most resistant. This may explain the moderate increase in the bacterial count.

\subsection{Excretion of ammonium of the mussels packaged in atmospheres $A, B$ and $C$}

The shell liquor of closed mussels was analyzed to quantify the ammonium excreted by the mussels as a metabolic degradation product and accumulated in the intervalval space. The batch 1 mussels packaged in the 3 atmospheres showed variable values throughout storage, yet they were always lower than $3 \mathrm{mg}$ per $\mathrm{L}$ of shell liquor (Fig. 2a). In batch 2 until day 9 , the values for $A, B$ and $C$ were very similar (Fig. 2b). In general, the ammonium concentrations for the mussels packaged in atmosphere B tended to be greater in this period and were significantly different with respect to atmospheres $\mathrm{A}$ and $\mathrm{C}$. Atmospheres $\mathrm{A}$ and $\mathrm{C}$ were not significantly different on day 6 and 9 of storage. From day 10 onwards there was a clear trend in ammonium concentration, being greater in $\mathrm{A}$ and lesser in $\mathrm{C}$ and all the differences were significant between the 3 atmospheres until day 13 of storage. On day 14 , atmospheres $A(77.2 \mathrm{mg} \mathrm{N} / \mathrm{L})$ and $B(74.0 \mathrm{mg} \mathrm{N} / \mathrm{L})$ were not significantly different, whereas the ammonium concentration in live mussels packaged under atmosphere $\mathrm{C}$ was $44.7 \mathrm{mg} \mathrm{N} / \mathrm{L}$. The profile and concentration of $\mathrm{N}$ in both batches were very different. It is notable that the value of ammonium excreted by the batch 2 mussels on day 3 of storage in the 3 atmospheres studied was not reached during the study period (14 days) in the batch 1 mussels.

The nitrogen from protein catabolism is transported to the haemolymph and is excreted as non-ionized ammonium which freely diffuses across the epithelium of the gills in response to the local concentration gradient. The elimination of this metabolite is made possible by the acidity of the water on the surface of the gills with the liberation of $\mathrm{CO}_{2}$. If the exterior concentration increases, the diffusive flux will vary and ammonium may accumulate in the body with deleterious consequences for the animal (Boyd \& Tucker, 1998). In general, the concentration of ammonium in the intervalval fluid was higher for batch 2 mussels than batch 1, which indicates that the former had a less favourable energy metabolism and, therefore, higher consumption of proteins in the accumulated reserves. This behavioural 
trend occurs under less favourable conditions such as in winter or in transplanted mussels and it is further known that the catabolic balance between proteins, carbohydrates and lipids varies with season and storage (Okumuş \& Stirling, 1994); Gabbott \& Bayne, 1973). The higher intervalval concentration may indicate the onset of ammonium accumulation in the tissues and could explain why the $20 \%$ mortality threshold occurs first in the batch 2 mussels for the 3 atmospheres studied (Table 2). The storage conditions for the two batches were identical and it is thus reasonable to assume that smaller mussels (batch 2) have higher energetic requirements. Hawkins, Bayne and Day (1986) found that mussel growth was genetic, whereby fast-growing mussels have reduced intensities of protein turnover and, thus, energy requirements. There was no clear difference in the ammonium nitrogen content of batch 2 mussels for all 3 atmospheres until day 10 of storage. However, atmosphere $C$ showed the lowest rate of accumulation until day 14 , which implies that the conditions were more favourable to the stability of these mussels compared to the other 2 atmospheres.

\subsection{Evolution of the total volatile acids (VFA) of batch 1 and 2 during storage} In shell liquor

The VFA content in shell liquor of the batch 1 mussels packaged in atmosphere $A$ was higher throughout storage (except for day 1) and was significantly different with respect to atmospheres B and C (Fig. 3a). Significant differences were observed between atmospheres $\mathrm{B}$ and $\mathrm{C}$ on day 1 and 7 , but none were observed on day 10 or 14 . Despite higher initial values with atmosphere $C$ than $B$, the VFA values of atmosphere $C$ were always lower for the rest of the storage period. The values reached on the last day of storage (day 14) were $0.709 \pm 0.042$ for $A, 0.256 \pm 0.005$ for $B$ and $0.220 \pm 0.034$ for the mussels packaged in atmosphere $\mathrm{C}$.

In batch 2 (Fig. 3b), atmosphere A was significantly different from B and C with higher values over the 14 day study period. The initial values with $B$ and $C$ were low $(<0.006 \mathrm{~g} / \mathrm{L})$ and differences between them could not be established. Yet, the differences were always 
significant between the samples in both atmospheres for the rest of the storage period, although the rate of VFA production was different as demonstrated by the intersection of the two curves in the figure. The values attained by day 14 were $1.016 \pm 0.017$ for $A, 0.665$ \pm 0.032 for $\mathrm{B}$ and $0.377 \pm 0.034$ for the mussels packaged in atmosphere $\mathrm{C}$.

Comparing batches on the days where analyses were performed (day 1, 10 and 14), the results show that atmospheres $A$ and $C$ of batch 1 were significantly different from those of batch 2 . For atmosphere $B$, day 10 was not significant between batches but was significant on day 1 and 14 . It is remarkable that the values for batch 1 on day 1 were greater than for batch 2 for the three atmospheres, whereas on day 10 and 14 they were lower. Regardless of the VFA values reached on each sampling day, the greatest difference between batches was due to the VFA production profile which is different for large (batch 1) and small mussels (batch 2).

In soft tissue

The VFA concentration in soft mussel tissue differed from that in the shell liquor. In batch 1 mussels (Fig. 4a), the concentrations for atmosphere A tended to be higher than those for atmospheres $B$ and $C$, but these differences were not always significant. Atmospheres $A$ and $B$ were not significantly different on day 7 storage due to the abnormally high standard deviation $(0.149 \pm 0.032)$ in the sequence for atmosphere $B$. Atmospheres $A$ and $B$ were significantly different on the other days of storage studied. The statistical analysis revealed that atmospheres $A$ and $C$ were different for the entire period except for day 2 . The samples for $B$ and $C$ were only different on day 14 with values of $0.219 \pm 0.003 \mathrm{gVFA} / \mathrm{Kg}$ and $0.133 \pm 0.003 \mathrm{gVFA} / \mathrm{Kg}$, respectively, versus $0.598 \pm 0.059 \mathrm{gVFA} / \mathrm{Kg}$ for the mussels packaged with atmosphere $\mathrm{A}$.

In batch 2 mussels (Fig. 4b), the VFA values for A were always higher and significantly different from $B$ and $C$ throughout the experiment. Over the same period, the values of atmospheres $B$ and $C$ were not significantly different between each other. The VFA values in soft tissue reached on day 14 of storage were $0.805 \pm 0.019$ for mussels in atmosphere A, $0.287 \pm 0.009$ for atmosphere $B$ and $0.271 \pm 0.044$ for atmosphere $C$. 
The VFA values at the end of storage for the three atmospheres of batch 1 were lower than the corresponding values of batch 2 (Fig. $4 a$ and $4 b$ ). Comparing batches on the days where analyses were performed (day 1,2 and 14), atmospheres $B$ and $C$ of batch 1 were significantly different from batch 2 . Differences could not be established between batch 1 and 2 for atmosphere $A$ on day 2. Furthermore, on day 10 of storage, the 3 atmospheres of batch 1 either had lower values $(A)$ or similar values ( $B$ and $C$ ) than batch 2 mussels on day 9.

The term volatile fatty acid (VFA) can refer to several different compounds, of which acetic, propionic, butyric and valeric acids are the most common. The fermentation products of carbohydrates in anaerobiosis of many invertebrates, such as bivalves, lead to the formation of volatile compounds, mainly acetate and propionate (van den Thillart \& de Vries, 1985). Studies with Mytilus edulis have shown that these compounds can accumulate in tissues even when there is diffusion of oxygen through gapping in mussels exposed to air (Widdows, Bayne, Livingstone, Newell \& Donkin, 1979). Variations in accumulation are caused by factors such as hypoxia, anoxia, temperature and seasonality (Wang et al., 1993; Zurburg \& Kluytmans, 1980). In this study, disparities in the accumulation of VFA in the atmospheres studied were also observed. Initially, $\mathrm{O}_{2}$ was available for respiration in the 3 atmospheres. However, the arrangements of the mussels inside the packages prevented them from opening their valves and, consequently, $\mathrm{O}_{2}$ consumption occurred by gapping. VFA accumulation was highest in atmosphere $A$ for both batches where the $\mathrm{O}_{2}$ concentration was very low towards the end of storage compared to atmospheres B and C (Table 3). Furthermore, the concentration of VFA in the intervalval fluid was greater than in the tissues for all the mussels analyzed, regardless of atmosphere or batch. Since VFAs have amphipathic properties, low molecular weights and are probably excreted by diffusion, Thillart et al. (1985) proposed that VFA concentrations in the ambient water at the site of cultivation could reflect the metabolic state of the mussels. Excretion is favoured by the $\mathrm{pH}$ of the tissues. However, continual production will lead to acidification of tissues and possibly death. Accordingly, high levels of acetate were 
observed when the majority of the individuals in the experiment were dead. The mortality of the mussels (Fig. 1) packaged with atmosphere A was $37 \%$ for batch 1 and $43 \%$ for batch 2 when high concentrations of VFA in the intervalval fluid and tissues were observed. The percentage mortality was lower for the mussels packaged in $\mathrm{O}_{2}$-rich atmospheres B and C.

In the first days of refrigerated storage, the larger mussels (batch 1) accumulated VFA in water and tissues in larger quantities than the smaller mussels (batch 2). However, the accumulation in the intervalval fluid and tissues became much more pronounced in batch 2 mussels from day 6 for those packaged under atmosphere $A$ and from day 9 for those packaged under $\mathrm{O}_{2}$-rich atmospheres ( $\mathrm{B}$ and $\mathrm{C}$ ). The metabolic behaviour of the mussels can be size-dependent since smaller individuals are generally capable of maintaining a more efficient aerobic metabolism due to higher surface area to volume ratio and the relatively shorter distance for oxygen. However, after an initial period, the energetic requirements of the smaller mussels could exceed a critical threshold and instigate death, as occurs with exposure to high temperatures (Wang et al., 1993; Hawkins, Wilson \& Bayne, 1987). The metabolic adjustment of molluscs to environmental conditions is also associated with a latency period after which the accumulation of VFAs can be detected (Thillart et al., 1985; Zurburg et al., 1980; Kluytmans et al., 1983).

3.4. Determination of the glycogen content in the digestive system in batch 1 and 2 during storage

The sample for analysis of glycogen in the hepatopancreas was derived from the dissection of 25 individuals. The size of the mussels chosen for dissection was representative of the mean size of the mussels in the 5 packages opened each sampling day. Table 4 presents data related to the digestive system. The dry weight of the collective sample of 25 hepatopancreas showed a clear difference between the 2 batches. The mean value of the samples calculated for the first 8 days of storage (independent of the packaging atmosphere) equalled $8.72 \pm 1.36 \mathrm{~g}$ for batch 1 and $3.90 \pm 0.39 \mathrm{~g}$ for batch 2 , 
which directly relates to the mussel size. On the other hand, a random variation occurred in the quantity of dry substance (Dw) for the atmospheres of batch 1, whereas in batch 2 this variation was smaller. Glycogen analysis was performed on day 10 of storage in batch 1 mussels where no trends were observed for any of the atmospheres. In batch 2 the analysis was postponed until day 14 of storage, where a similar oscillation in the glycogen content for the mussels packaged in the 3 atmospheres ( $A, B$ and $C$ ) was observed, but with lower values at the end of this period (8.48, 13.4 and 11.3 , respectively).

Also shown in Table 4 is the ratio of dry to wet substances (\% Dw/ Ww) of the 25 hepatopancreas of batch 2 obtained each sampling day. As for glycogen, no clear trend was observed although there were notable values on day 14 of storage $(16.6 \%$ for $A$, $24.9 \%$ for $B$ and $26.4 \%$ for $C$ ). Despite the difference in size of the mussels or the weight of the hepatopancreas, the proportion of glycogen in the 2 batches was similar. For batch 1 , the mean values over the first 8 days of storage were $16.8 \pm 1.8$ for $A, 18.2 \pm 1.3$ for $B$ and $16.5 \pm 1.0$ for $\mathrm{C}$ and the differences between them were not significant. For batch 2 , the mean values were $16.7 \pm 2.1$ for $A, 15.5 \pm 2.9$ for $B$ and $14.2 \pm 2.8$ for $C$ and, again, the differences were not significant between the 3 atmospheres. The statistical analysis of $A / A, B / B$ and $C / C$ of the 2 batches also indicates that they were not significantly different. Molluscs store glycogen in different parts of their anatomy as an energy source. An increase or decrease in glycogen follows seasonal cycles, temperature, food availability and gametogenesis, among others. Consumption can be caused by stress factors such as contamination or manipulation during cultivation (Fraga, 1956; Hummel, Dewolf, Zurburg, Apon, Bogaards \& Vanruitenburg, 1989). Studies on the accumulation of glycogen in diverse parts of the anatomy and its seasonal evolution show that the largest variations occur in the mantle and hepatopancreas. Zwaan studied glycogen degradation in mussels under anaerobic conditions, and the consumption over $48 \mathrm{hr}$ was about $25 \%$ of the total glycogen stored in the digestive gland and muscles including the foot (de Zwaan \& Zandee, 1972). The results obtained here showed small differences in glycogen consumption. In batch 1 , there was a tendency for consumption for the 3 gas mixtures. 
Yet, differences could not be established between the atmospheres due to the variability in the data and the short study period. A high variability in the weight of the hepatopancreas recovered each sampling day was also observed for batch 1 mussels, which could be the reason for not being able to identify a clear trend in glycogen consumption. It would be thus more informative to do the analysis on individuals and study the behaviour of the population reflecting the variance. Due to the distribution or agglomeration of mussels on the cultivation ropes, not all mussels extracted on the same day will have the same condition or composition. For example, growth and energy balance studies have shown that differences exist in the growth of mussels of the same age. Furthermore, the fixed raft system does not lead to consistent growth of mussels since one side will tend to be more exposed to food resources (Camacho et al., 2000; Karayücel \& Karayücel, 2000). The analysis of glycogen in batch 2 mussels was extended to day 14 even though they would have been rejected following organoleptic assessment. In this batch, a tendency towards glycogen consumption was observed for the 3 atmospheres, especially in the mussels packaged under atmosphere A. The ratio of the dry weight of the hepatopancreas to the wet weight on day 14 of storage was most notable, indicating a consumption of energetic reserves accumulated in the digestive gland. Concurrently, the $\mathrm{O}_{2}$ consumption in the packages was continuous, with low values recorded for $A$ on day $14\left(4.2 \pm 3.5 \% \mathrm{O}_{2}\right)$ and high values in the other atmospheres $\left(62.4 \pm 4.5\right.$ in $\mathrm{B}$ and $63.1 \pm 4.2 \% \mathrm{O}_{2}$ in $\left.\mathrm{C}\right)$.

The mussel digestive gland is a site of intracellular digestion and carbon assimilation and is also used for storage of metabolic reserves. The variability in the weight of the hepatopancreas to total weight has been studied with regard to, for example, seasonal cycles, gametogenesis and changes in environmental parameters. Fluctuations in this ratio were similar to those for glycogen and lipid concentration in the digestive gland. Glycogen concentrations depend on environmental stresses and there is a heavy dependence on glycolysis during anaerobic periods. The initial absence of a decrease in glycogen content during long term anoxia seems to be a general characteristic of bivalves, especially for those species which posses a high glycogen content (Hummel et al., 1989; Isani, Cattani, 
Zurzolo, Pagnucco \& Cortesi, 1995; Cartier, Pellerin, Fournier, Tamigneaux, Girault \& Lemaire, 2004). Uzaki, Kai, Aoyama and Suzuki (2003) also noted that glycogen was a good indicator of the physiological condition of $R$. philippinarum exposed to oxygendeficient waters, although the response was only detected following long exposure to stress.

\section{Conclusion}

The results obtained allow the following conclusions to be made: (1) packaging atmospheres with richer oxygen concentrations favour the stability of live Mediterranean mussels stored at $2 \pm 1{ }^{\circ} \mathrm{C},(2)$ at higher $\mathrm{O}_{2}$ concentrations, the packaged mussels tend to produce less metabolic products, and (3) the metabolism of the live mussels packaged in modified atmospheres depends on their size. For commerce, where a mixture of sizes is usual, a very high quality of Mediterranean mussels independent of size and after 8 days of refrigerated storage would be obtained with packaging atmospheres of $75-85 \% \mathrm{O}_{2}$. In these mussels, the quantity of metabolites is low and had no effect on the sensorial analysis of the cooked product.

\section{Acknowledgments}

The authors wish to thank Alberto Gallego and Bibiana Torres for their technical assistance. This research was supported by European Project 2-05 AL, AquaGair. 
Fig. 1. Percentage mortality of Mediterranean mussels packaged with different initial concentrations of oxygen; A (20\%), B (75\%) and C (85\%) for (a) batch 1 (large mussels) and (b) batch 2 (small mussels). Vertical bars represent the standard error.
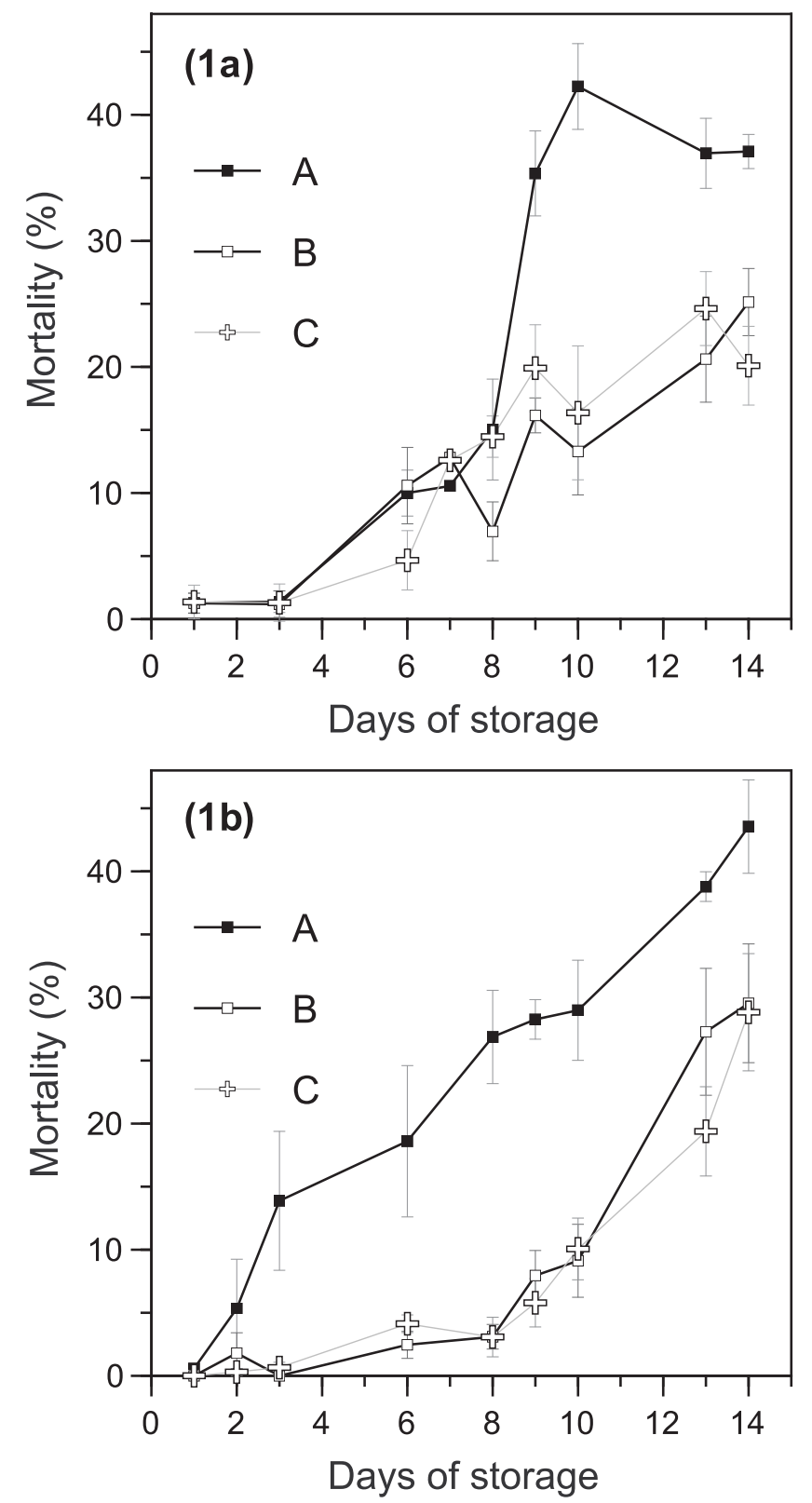
Fig. 2. Concentration of ammonium nitrogen in Mediterranean mussels packaged with different initial concentrations of oxygen. Nomenclature as in Fig. 1.
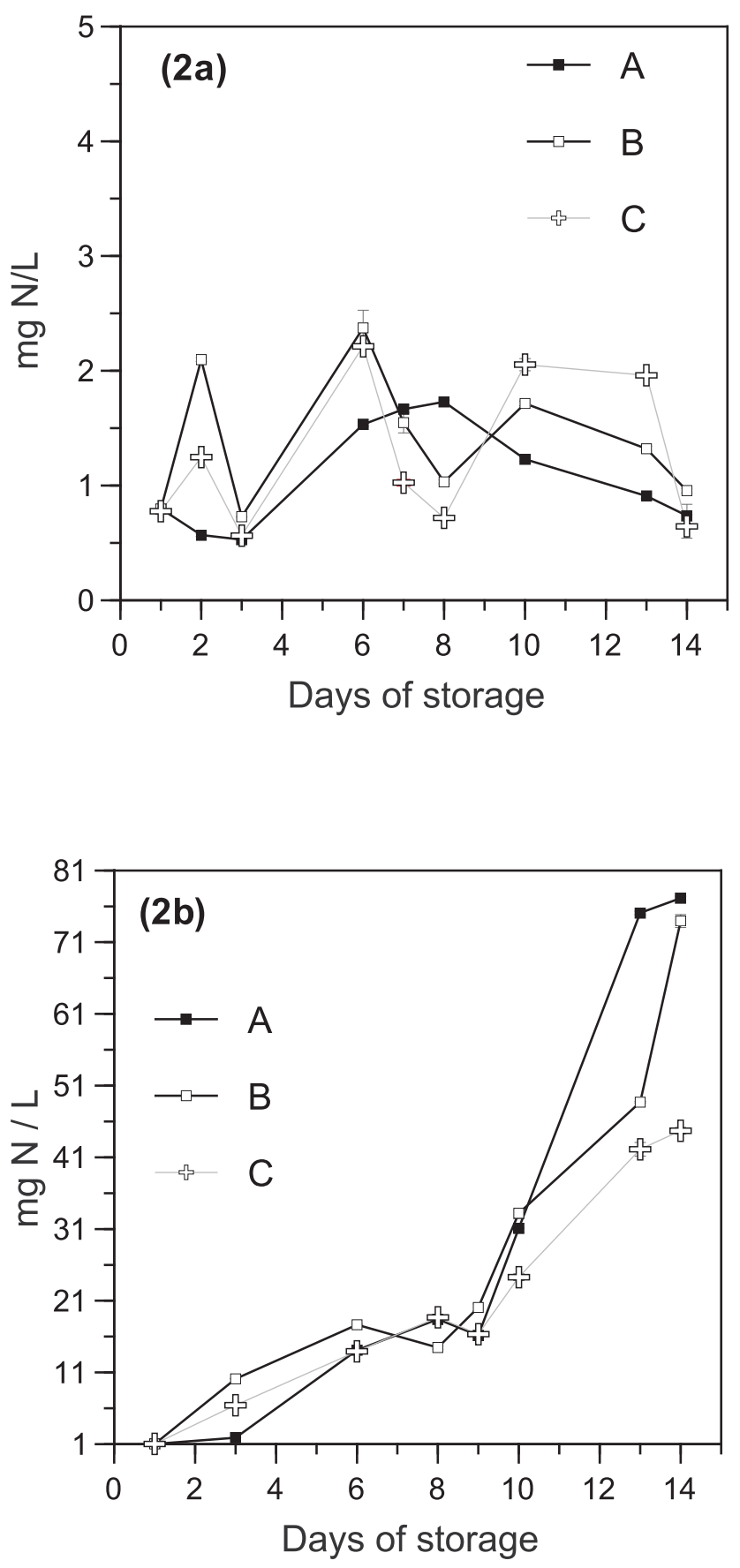
Fig. 3. Concentration of volatile fatty acids in shell liquor in Mediterranean mussels packaged with different initial concentrations of oxygen. Nomenclature as in Fig. 1
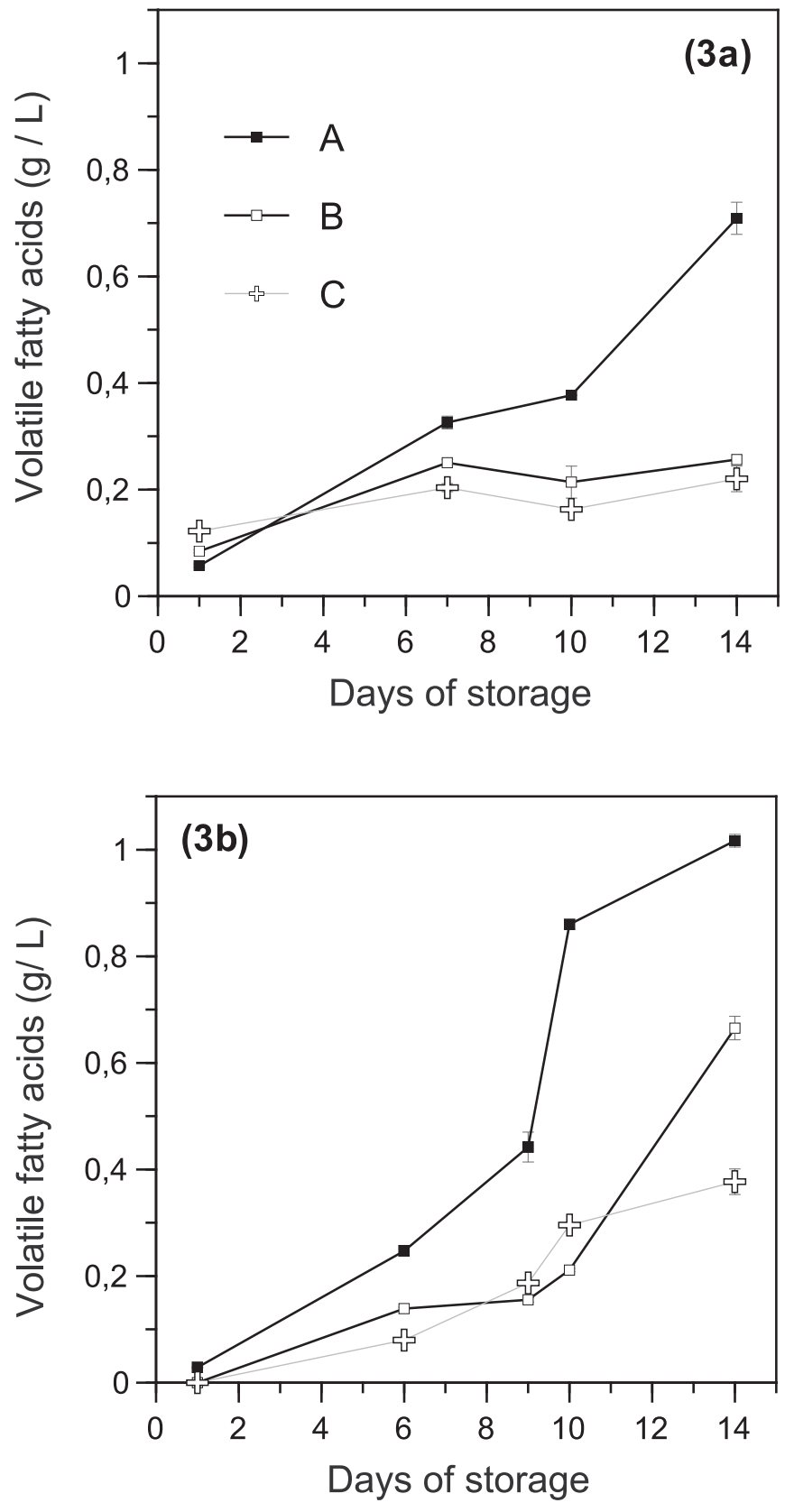
Fig. 4. Concentration volatile fatty acids in soft tissue in Mediterranean mussels packaged with different initial concentrations of oxygen. Nomenclature as in Fig. 1.
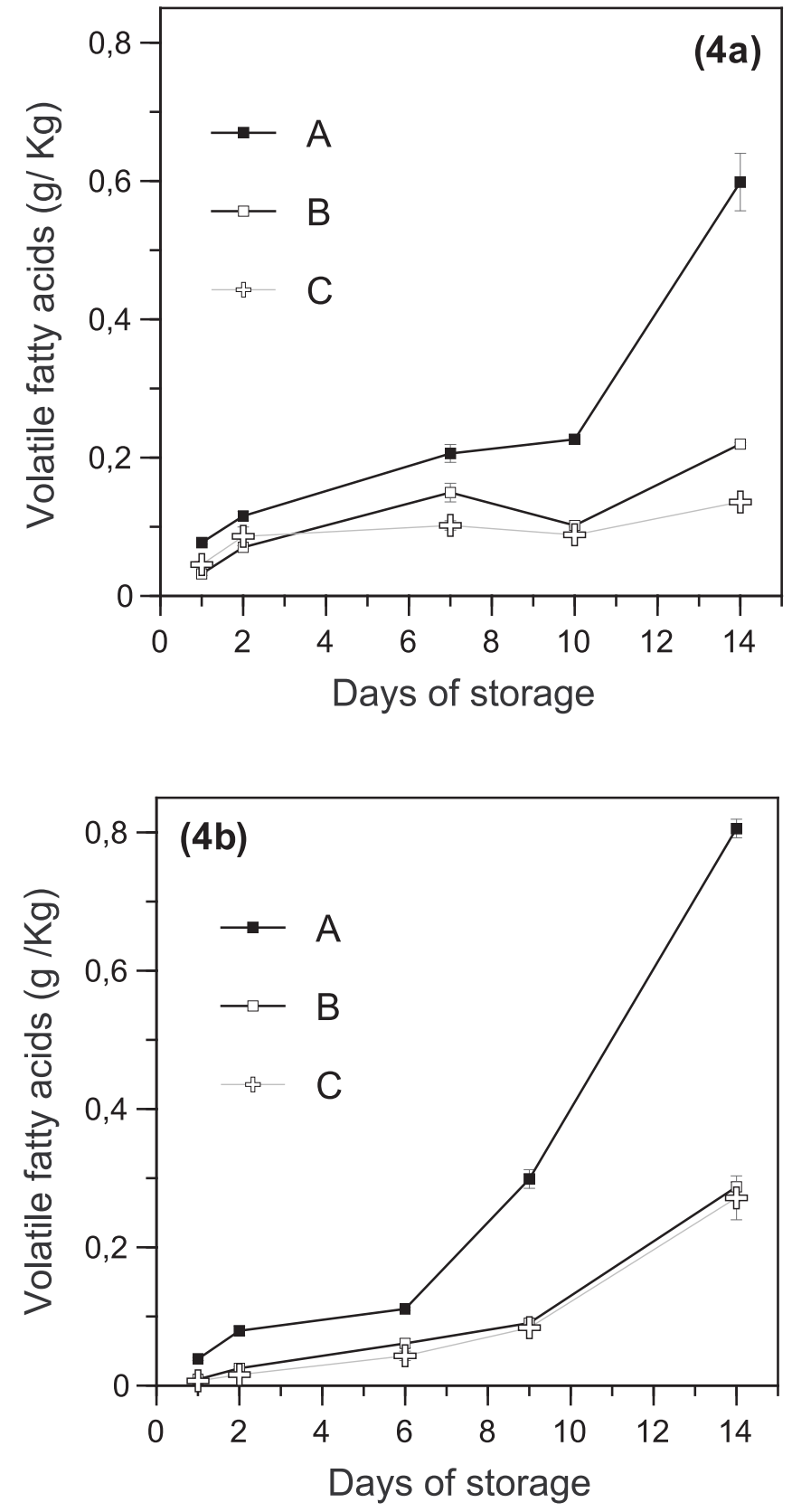
Table 1

Size and proximate composition of Mediterranean mussels.

\begin{tabular}{lccc}
\hline & Batch 1 & & Batch 2 \\
\cline { 2 - 2 } Shell length $(\mathrm{cm})$ & $7.9(0.8) \mathrm{a}$ & & $6.7(0.9) \mathrm{b}$ \\
Shell width $(\mathrm{cm})$ & $3.9(0.3) \mathrm{a}$ & & $3.3(0.4) \mathrm{b}$ \\
Tissue $(\mathrm{g} /$ mussel)* & 1.770 & & 1.128 \\
Protein* $^{*}$ & $59.8(0.6) \mathrm{a}$ & & $58.9(1.3) \mathrm{a}$ \\
Lipids* $^{*}$ & $5.5(0.0) \mathrm{a}$ & & $7.3(0.1) \mathrm{b}$ \\
Carbohydrates $^{*}$ & $27.9(0.3) \mathrm{a}$ & & $24.9(1.0) \mathrm{b}$ \\
Ashes $^{*}$ & $6.8(0.2) \mathrm{a}$ & & $8.9(0.0) \mathrm{b}$ \\
\hline
\end{tabular}

*In dry weight

Standard desviation in brackets; a-b are significantly different $(p<0.05)$

Shell size, $n=25$; Proximal composition, $n=3$

Table 2

Significant differences of percentage mortality between the different packages.

\begin{tabular}{|c|c|c|c|c|c|c|c|c|c|}
\hline \multirow[b]{2}{*}{ Day } & \multicolumn{3}{|c|}{ Batch 1} & \multicolumn{3}{|c|}{ Batch 2} & \multicolumn{3}{|c|}{ Batch 1 / Batch 2} \\
\hline & $\mathrm{A}$ & B & C & A & $\mathrm{B}$ & $\mathrm{C}$ & $\mathrm{A} / \mathrm{A}$ & $\mathrm{B} / \mathrm{B}$ & $\mathrm{C} / \mathrm{C}$ \\
\hline 1 & a & a & a & a & a & $a$ & - & - & - \\
\hline 3 & a & a & a & a & $b$ & $\mathrm{~b}$ & - & - & - \\
\hline 6 & a & a & $a$ & a & $\mathrm{b}$ & $\mathrm{b}$ & - & $*$ & - \\
\hline 8 & $a b$ & a & $b$ & a & $b$ & $\mathrm{~b}$ & $*$ & - & $*$ \\
\hline 9 & a & $\mathrm{b}$ & $b$ & a & $\mathrm{b}$ & $\mathrm{b}$ & $*$ & * & * \\
\hline 10 & a & $b$ & $\mathrm{~b}$ & a & $\mathrm{b}$ & $\mathrm{b}$ & $*$ & - & - \\
\hline 13 & $a$ & $\mathrm{~b}$ & $b$ & a & $a b$ & $\mathrm{~b}$ & - & - & - \\
\hline 14 & $a$ & $b$ & $b$ & $a$ & $b$ & $\mathrm{~b}$ & - & - & - \\
\hline
\end{tabular}

$a-b$ are significantly different $(p<0.05)$ between atmospheres A, B and C Symbol $*$ or - are or are not significantly different $(p<0.05)$ between batches, respectively 
Table 3

Organoleptic results, \% oxygen and $\mathrm{pH}$ in the intervalval liquid and in tissue of the mussels batches packaged under modified atmospheres on day 8 and 13 of refrigerated storage $\left(2^{\circ} \mathrm{C}\right)$.

Batch 1

Batch 2

\begin{tabular}{|c|c|c|c|c|c|c|c|c|c|}
\hline $\mathrm{Atm}^{1}$ & Day & Cooked & $\% \mathrm{O}_{2}$ & Sh lq pH ${ }^{2}$ & Tiss $\mathrm{pH}^{3}$ & Cooked & $\% \mathrm{O}_{2}$ & Sh lq pH & Tiss $\mathrm{pH}$ \\
\hline Air & 0 & $9.7(0.5)$ & $20.9(0.1)$ & $7.30(0.01)$ & $6.60(0.03)$ & $9.7(0.5)$ & $20.9(0.1)$ & $7.40(0.02)$ & $6.70(0.04)$ \\
\hline \multirow[t]{2}{*}{ A } & 8 & $6.1(0.2)$ & $7.2(2.3)$ & $7.08(0.02)$ & $6.46(0.02)$ & $6.3(0.5)$ & $13.0(1.8)$ & $6.79(0.01)$ & $6.38(0.04)$ \\
\hline & 13 & unfit & $2.5(1.7)$ & n.a & $6.40(0.03)$ & unfit & $5.0(3.4)$ & $6.38(0.03)$ & $6.29(0.02)$ \\
\hline \multirow[t]{2}{*}{$B$} & 8 & $8.2(0.2)$ & $69.4(2.5)$ & $7.25(0.02)$ & $6.50(0.02)$ & $8.2(0.2)$ & $70.8(1.2)$ & $7.38(0.01)$ & $6.65(0.02)$ \\
\hline & 13 & $6.6(0.6)$ & $65.7(2.7)$ & $6.92(0.01)$ & $6.67(0.03)$ & $4.1(0.3)$ & $64.1(2.9)$ & $6.72(0.02)$ & $6.65(0.03)$ \\
\hline \multirow[t]{2}{*}{ C } & 8 & $8.2(0.2)$ & $73.8(1.3)$ & $7.28(0.01)$ & $6.58(0.02)$ & $8.4(0.3)$ & $77.8(1.0)$ & $7.28(0.02)$ & $6.59(0.03)$ \\
\hline & 13 & $6.2(0.9)$ & $69.6(1.5)$ & $7.01(0.03)$ & $6.60(0.03)$ & $6.7(0.5)$ & 65.3 (3.9) & $6.80(0.03)$ & $6.63(0.05)$ \\
\hline
\end{tabular}

1 Atmosphere; 2 Shell liquor $\mathrm{pH}$; 3 Tissue $\mathrm{pH}$; n.a not analysed

Table 4

Glycogen content and weight of the hepatopancreas during storage of the 2 batches of packaged Mediterranean mussels.

\begin{tabular}{|c|c|c|c|c|c|c|}
\hline \multirow[b]{2}{*}{$\mathrm{Atm}^{1}$} & \multirow[b]{2}{*}{ Day } & \multicolumn{2}{|c|}{ Batch 1} & \multicolumn{3}{|c|}{ Batch 2} \\
\hline & & $\mathrm{Glu}^{2} \%$ & $\mathrm{Dw}^{3}(\mathrm{~g})$ & Glu \% & Dw (g) & $\mathrm{Dw} / \mathrm{Ww}^{4}(\%)$ \\
\hline \multirow{6}{*}{ A } & 1 & 19,2 & 8.44 & 17,7 & 4.09 & 27,8 \\
\hline & 3 & 16,5 & 9.19 & 19,1 & 3.70 & 27,5 \\
\hline & 6 & 15,0 & 7.21 & 15,2 & 4.08 & 27,5 \\
\hline & 8 & 16,5 & 10.2 & 14,6 & 3.29 & 27,9 \\
\hline & 10 & 17,7 & 6.96 & * & * & * \\
\hline & 14 & $*$ & * & 8,5 & 2.91 & 16,6 \\
\hline \multirow{6}{*}{ B } & 1 & 17,5 & 6.39 & 16,1 & 4.03 & 29,1 \\
\hline & 3 & 20,0 & 9.24 & 18,8 & 3.69 & 30,2 \\
\hline & 6 & 17,1 & 9.16 & 11,8 & 3.43 & 27,8 \\
\hline & 8 & 18,4 & 9.45 & 15,5 & 3.95 & 28,6 \\
\hline & 10 & 19,8 & 9.09 & * & * & * \\
\hline & 14 & * & * & 13,4 & 3.92 & 24,9 \\
\hline \multirow{6}{*}{ C } & 1 & 17,7 & 7.48 & 16,4 & 4.32 & 27,5 \\
\hline & 3 & 15,9 & 8.33 & 12,7 & 3.70 & 30,9 \\
\hline & 6 & 15,5 & 11.4 & 11,0 & 4.27 & 28,6 \\
\hline & 8 & 17,0 & 8.13 & 16,8 & 4.46 & 23,9 \\
\hline & 10 & 19,4 & 8.04 & * & * & * \\
\hline & 14 & $*$ & * & 11,3 & 3.56 & 26,4 \\
\hline
\end{tabular}

1 Atmosphere; 2 glycogen; 3 dry weight; 4 wet weight 


\section{References}

Anonymous. (1992). Microbiological criteria for raw molluscan shelfish. Journal of Food Protection, 55, 667671.

AOAC. (1990a, b, c, d). Official Methods of Analysis (15 ${ }^{\text {th }}$ edn), vol 2. (pp. 868, 931,871, 873). Arlington.

Babarro, J. M. F., Fernández-Reirez, M. J., \& Labarta, U. (2000). Metabolism of the mussel Mytilus galloprovincialis from two origins in the Ría de Arousa (north-west Spain). Journal of the Marine Biological Association of the United Kingdom, 80, 5, 865-872.

Bayne, B. L., Thompson, R. J., \& Widdows, J. (1976). Physiology I. In B. L. Bayne (Eds.), Marine mussels: their ecology and physiology (pp. 121-206). Cambridge: Cambridge University Press.

Boyd, C. E. (1998). Water quality requirements. In C. E. Boyd \& C. S. Tucker (Eds.), Pond aquaculture water quality management (Cap 3). Boston: Kluwer Academic Publishers.

Camacho, A. P., Labarta, U., \& Navarro, E. (2000). Energy balance of mussels Mytilus galloprovincialis: The effect of length and age. Marine Ecology Progress Series, 199, 149-158.

Cartier, S., Pellerin, J., Fournier, M., Tamigneaux, E., Girault, L., \& Lemaire, N. (2004). Use of an index based on the blue mussel (Mytilus edulis and Mytilus trossulus) digestive gland weight to assess the nutritional quality of mussel farm sites. Aquaculture, 241, 633-654.

Ekanem, E. O., \& Achinewhu, S. C. (2006). Mortality and quality indices of live West African hard-shell clams (Galatea paradoxa Born) during wet and dry postharvest storage. Journal of Food Processing and Preservation, 30, 3, 247-257.

Erkan, N. (2005). Changes in quality characteristics during cold storage of shucked mussels (Mytilus galloprovincialis) and selected chemical decomposition indicators. Journal of the Science of Food and Agriculture, 85, 15, 2625-2630.

FAO. (2007). Bivalves. Globlefish Commodity update reports, 10. Web site www.globefish.org

FAO. (2008). European fish price report. Globefish European Price Report, 10.

Farber, J. M., \& Dodds, K. L. (1995). Principles of modified atmosphere and sous vide product packaging. Farber and Dodds (Eds.). Pennsylvania: Lancaster.

Fraga, F. (1956). Determinación de glucógeno en moluscos con el reactivo de antrona. Investigación Pesquera, 3, 69-74.

Fraga, F. (1956). Variación estacional de la composición química del mejillón (Mytilus edulis) I. Investigación Pesquera, 4, 109-125. 
Gabbott, P. A., \& Bayne, B. L. (1973). Biological effects of temperature and nutritive stress on Mytilus edulis (I). Journal of the Marine Biological Association of the United Kingdom, 53, 269-286.

Gonçalves, A., Pedro, S., Duarte, A., \& Nunes, M. L. (2009). Effect of enriched oxygen atmosphere storage on the quality of live clams (Ruditapes decussatus). International Journal of Food Science \& Technology, 44, 2598-2605.

Goulas, A. E., Chouliara, I., Nessi, E., Kontominas, M. G., \& Savvaidis, I. N. (2005). Microbiological, biochemical and sensory assessment of mussels (Mytilus galloprovincialis) stored under modified atmosphere packaging. Journal of Applied Microbiology, 98, 752-760.

Hawkins, A. J. S., Bayne, B. L., \& Day. A. J. (1986). Protein turnover, physiological energetics and heterozygosity in the blue mussel, Mytilus edulis: the basis of variable age specific growth. Proceedings of the Royal Society, London, Series B, 119, 161-176.

Hawkins, A. J. S., Wilson, I. A., \& Bayne, B. L. (1987). Thermal responses reflect protein turnover in Mytilus edulis L. Functional Ecology, 1, 4, 339-351.

Heisler, N. (1986). Buffering and transmembrane ion transfer processes. In N. Heisler (Ed.), Acid-base regulation in animals (pp. 3-47). Amsterdam: Elsevier Science Publisher BV.

Ho, Y. C., Lee, T-Ch., \& Yam, K. L. (1997). Respiration rates of live clams (Mercenaria mercenaria; Hard clams) in modified atmospheres at various temperatures. Journal of Aquatic Food Product Technology, 6(1), 37-51.

Hummel, H., Dewolf, L., Zurburg, W., Apon, L., Bogaards, R. H., \& Vanruitenburg, M. (1989). The glycogencontent in stressed marine bivalves - the initial absence of a decrease. Comparative Biochemistry and Physiology B-Biochemistry \& Molecular Biology, 94, 729-733.

Isani, G., Cattani, O., Zurzolo, M., Pagnucco, C., \& Cortesi, P. (1995). Energy metabolism of the mussel, Mytilus galloprovincialis, during long-term anoxia. Comparative Biochemistry and Physiology B-Biochemistry \& Molecular Biology, 110B(1), 103-113.

Jokumsen, A., \& Fyhn, H. J. (1982). The influence of aerial exposure upon respiratory and osmotic properties of haemolymph for two intertidal mussels, Mytilus edulis $L$. and Modiolus demissus L. Journal of Experimental Marine Biology and Ecology, 61 (2), 189-203.

Karayücel, S., \& Karayücel, İ. (2000). The effect of environmental factors, depth and position on the growth and mortality of raft-cultured blue mussels (Mytilus edulis L.). Aquaculture Research, 31, 12, 893-899.

Khan, M. A., Parrish, C. C., \& Shahidi, F. (2005). Enumeration of total heterotrophic and psychrotrophic bacteria using different types of agar to evalute the microbial quality of blue mussels (Mytilus edulis) and sea scallops (Placopecten magellanicus). Food Research International, 38, 751-758.

Kluytmans, J. H., \& Zandee, D. I. (1983). Comparative study of the formation and excretion of anaerobic fermentation products in bivalves and gastropods. Comparative Biochemistry and Physiology, 4, 729-732. 
Okumuş, I., \& Stirling, H. P. (1994). Physiological energetics of cultivated mussel (Mytilus edulis) populations in 2 Scottish West-Coast sea lochs. Marine Biology, 119, 125-131.

Parsons, T. R. (1984). A manual of chemical and biological methods for seawater analysis. T. R. Parsons, Y. Maita \& C. M. Lalli (Eds.). Oxford: Pergamon Press.

Pastoriza, L., Bernárdez, M., Sampedro, G., Cabo, M. L., \& Herrera, J. J. R. (2004). Elevated concentrations of oxygen on the stability of live mussel stored refrigerated. European Food Research and Technology, 218, 415-419.

Pérez Camacho, A., González, R., \& Fuentes, J. (1991). Mussel culture in Galicia (N.W. Spain). Aquaculture, 94(2-3), 263-278.

Ribas, I., \& Vázquez, G. D. (1953). Estudio de la mineralización de la materia orgánica en el método Kjeldahl. Información de Química Analítica, 7, 2-3.

Sadok, S., Uglow, R. F., \& El-Abed, A. (2003). Nitrogenous compound changes in live, stored clam, Tapes decussatus: the effects of temperature and emersion. Journal of Aquatic Food Product Technology, 12, 4, 113-128.

Sukhotin, A. A., \& Portner, H. O. (1999). Habitat as a factor involved in the physiological response to environmental anaerobiosis of White Sea Mytilus edulis. Marine Ecology Progress Series, 184, 149-160.

Sukhotin, A. A., Lajus, D. L., \& Lesin, P. A. (2003). Influence of age and size on pumping activity and stress resistance in the marine bivalve Mytilus edulis L. Journal of Experimental Marine Biology and Ecology, 284, $1-2,129-144$.

Svensson, A. (2004). Active food packaging - materials and interactions. A literature review. SIK-Rapport, 727.

van den Thillart, G., \& de Vries, I. (1985). Excretion of volatile fatty acids by anoxic Mytilus edulis and Anodonta cygnea. Comparative Biochemistry and Physiology B-Biochemistry \& Molecular Biology, 80B(2), 299-301.

Uzaki, N., Kai, M., Aoyama, H., \& Suzuki, T. (2003). Changes in mortality rate and glycogen content of the Manila clam Ruditapes philippinarum during the development of oxygen-deficient waters. Fisheries Science, 69, 5, 936-943.

Wang, W. X., \& Widdows, J. (1993). Metabolic responses of the common mussel Mytilus edulis to hypoxia and anoxia. Marine Ecology Progress Series, 95, 3, 205-214.

Widdows, J., Bayne, B. L., Livingstone, D. R., Newell, R. I. E., \& Donkin, P. (1979). Physiological and biochemical responses of bivalve molluscs to exposure to air. Comparative Biochemistry and Physiology, 62A(2), 301-308. 
Zurburg, W., \& Kluytmans, J. H. (1980). Organ specific changes in energy metabolism due to anaerobiosis in the sea mussel Mytilus edulis (L.). Comparative Biochemistry and Physiology B-Biochemistry \& Molecular Biology, 67(2), 317-322.

de Zwaan, A., \& Zandee, D. I. (1972). Body distribution and seasonal-changes in glycogen content of common sea mussel Mytilus edulis. Comparative Biochemistry and Physiology, 43(1A), 53-58.

de Zwaan, A., Babarro, J. M. F., Monari, M., \& Cattani, O. (2002). Anoxic survival potential of bivalves: (arte)facts. Comparative Biochemistry and Physiology A-Molecular \& Integrative Physiolog, 131, 3, 615-624. 